\title{
PENGARUH BRAND EQUITY DAN BRAND TRUST TERHADAP LOYALITAS PELANGGAN TEH BOTOL SOSRO DI KOTA BANDUNG
}

\author{
Teguh Iman Basuki \\ STIE EKUITAS \\ Jl. PH.H. Mustofa No.31, Bandung, Jawa Barat \\ teguhib@ekuitas.ac.id
}

\begin{abstract}
Currently the competition to attract consumers to use the product is no longer limited to promoting the initial functionality of a product but it will always be associated with the image of the product itself. The strength of a brand or brand Equity of a product is formed from the process of applying a good marketing strategy in shaping a brand while a product that is trusted by a consumer is a product that has a high brand trust because the product gives high satisfaction value to the consumer. This research is to know the influence of brand equity and brand trust to customer loyalty of Bottle Sosro Tea to Active Student of S1 STIE EQUITY STAFF STUDY 2011-2013, with member of population as much as 975 people, questionnaires distributed to 91 respondents by using error rate equal to $10 \%$. The research method used is survey method, while data collection technique is done through interview and questionnaire. The analytical tool used is Line Analysis using IBM SPSS 20.0. The result of the research shows that there are significant positive influence either partially or simultaneously brand equity and brand trust to loyalty.
\end{abstract}

Keywords: brand equity, brand trust, and customer loyalty

\section{PENDAHULUAN}

Pertumbuhan satu perusahaan bergantung kepada bagaimana perusahaan tersebut dapat memenangkan persaingan bisnis, saat ini ditengah persaingan antara barat dan timur yang ditandai dengan perang mata uang terutama antara Amerika Serikat (USA) dengan Tiongkok akan bisa menyebabkan persaingan bisnis semakin ketat yang pada ujungnya adalah perusahaan kesulitan untuk mendapatkan atau meningkatkan jumlah konsumen pada pasar yang sudah ada. Dalam kondisi seperti ini perusahaan dituntut untuk dapat bertahan hidup bahkan perusahaan juga dituntut untuk melakukan peningkatan dalam pengembangan perusahaan karena perusahaan dihadapkan pada persaingan ketat yang memiliki kompleksitas tinggi serta perubahan iklim lingkungan bisnis yang demikian cepat yang pada akhirnya mempertahankan loyalitas konsumen sudah merupakan kewajiban, walaupun produk yang dihasilkan oleh perusahaan tersebut sudah memiliki pangsa pasar tertentu jika loyalitas konsumen tidak dapat dijaga maka akan terjadi perpindahan merek, hal tersebut dapat terjadi karena adanya persaingan yang sangat ketat dan agesif yang terkadang sengaja diarahkan untuk meruntuhkan loyalitas konsumen terhadap satu merek produk. Merek (brand) merupakan sebuah pembeda dari setiap produk serta dapat menunjukkan kepercayaan dan kualitas pada konsumen dan mempengaruhi penjualan. Kepercayaan merek (brand trust) merupakan komponen penting dalam meningkatkan loyalitas konsumen, banyak merek yang sudah tidak dikenal dan diingat konsumen dan mengakibatkan perindahan merek hal ini dapat disebabkan kepercayaan merek terhadap produk tertentu oleh kosnumen mulai hilang. Kondisi tersbut juga dapat terjadi pada industri minuman ringan dalam kemasan. PT Teh Botol Sosro yang merupakan produsen minumana teh dalam kemasan "Teh Botol Sosro" yang dimulai sejak tahun 1940, dalam rangka meningkatkan dan mempertahankan loyalitas konsumen selalu mempertahan mutu 
prouduknya serta telah melakukan perubahan desain botol sebanyak 3 versi, sehingga perubahan tersebut menimbulkan banyakk kompetitor baru. Tujuan penelitian adalah untuk mengetahui seberapa besar pengaruh brand equity dan brand trust terhadap loyalitas pelanggan Teh Botol Sosro

\section{KAJIAN PUSTAKA}

\subsection{Pengertian Pemasaran}

Kegiatan pemasaran sering diartikan sebagai kegiatan dalam memasarkan suatu produk yang diperjual belikan oleh perusahaan dan ditujukan untuk memenuhi kebutuhan konsumen. Namun jika dilihat makna sebenarnya pemasaran bukan hanya sekedar menjual produk saja, akan tetapi pemasaran juga memiliki aktvitas penting dalam menganalisis dan mengevaluasi segala kebutuhan dan keinginan para konsumen. Pemasaran juga meliputi segala aktivitas di dalam perusahaan. Menurut Kotler dan Keller (2009:5) definisi pemasaran sebagai berikut: "Pemasaran adalah sebuah proses kemasyarakatan di mana individu dan kelompok memperoleh apa yang mereka butuhkan dan inginkan dengan menciptakan, menawarkan, dan secara bebas mempertukarkan produk dan jasa yang bernilai dengan orang lain". Menurut Saladin $(2006 ; 1)$ istilah pemasaran dapat diartikan yaitu : "Pemasaran adalah suatu sistem total dari kegiatan bisnis yang dirancang untuk merencanakan, menentukan harga, promosi dan mendistribusikan barang-barang yang dapat memuaskan keinginan dan mencapai pasar sasaran serta tujuan perusahaan".

\subsection{Pengertian Merek (brand)}

Dewasa ini merek memainkan sejumlah peran penting untuk meningkatkan hidup konsumen dan nilai keuangan perusahaan. Asosiasi Pemasaran Amerika dalam Kotler (2007:232) mendefinisikan bahwa merek adalah : "Nama, istilah, tanda, simbol atau rancangan atau kombinasi dari semuanya, yang dimaksudkan untuk mengidentifikasi barang atau jasa penjual atau kelompok penjual dan untuk mendiferensiasikan dari barang atau jasa pesaing." Sedangkan menurut William J. Stanton definisi dari merek adalah nama, istilah, simbol atau desain khusus atau beberapa kombinasi unsur-unsur ini yang dirancang untuk mengidentifikasikan barang atau jasa yang ditawarkan oleh penjual. Menurut pendapat diatas dapat disimpulkan bahwa sebuah merek adalah sebuah produk atau jasa penambah dimensi yang dengan cara tertentu mendiferensiasikannya dari prosuk atau jasa lain yang dirancang untuk memuaskan kebutuhan yang sama.

\subsection{Pengertian Ekuiitas Merek (Brand Equity)}

Menurut Aaker (2006 : 22) mengemukakan definisi dari brand equity yaitu seperangkat asset dari liabilitas merek yang berkualitas dengan suatu merek, nama dan simbolnya, yang menambah atau mengurangi nilai yang diberikan oleh sebuah barang atau jasa kepada perusahaan atau para pelanggan perusahaan. Sedangkan pengertian brand equity menurut Kotler dan Keller (2009:334) yaitu nilai tambah yang diberikan pada produk dan jasa, nilai ini biasanya dicerminkan dalam cara konsumen berfikir, merasa dan bertindak terhadap merek, harga, pangsa pasar, dan profitabilitas yang dimiliki perusahaan.

\subsection{Pengertian Kepercayaan Merek (Brand Trust)}

Menurut Lau dan Lee (2007:28) kepercayaan pelanggan pada merek (brand trust) didefinisikan keinginan pelanggan untuk bersandar pada sebuah merek dengan risiko-risiko yang dihadapi karena ekspektasi terhadap merek itu akan menyebabkan hasil yang positif. Menurut 
Costabile dikutip oleh Ferrinadewi (2008:146) kepercayaan merek adalah persepsi akan kehandalan dari sudut pandang konsumen didasarkan pada pengalaman atau lebih pada urut-urutan transaksi atau interaksi yang dicirikan oleh terpenuhinya harapan akan kinerja produk dan kepuasan. Morgan dan Hunt (2005;21) mengonseptualisasikan trust (kepercayaan) ketika satu kelompok memiliki keyakinan bahwa partner pertukaran memiliki reliabilitas dan integritas. Kepercayaan sebagai suatu keadaan yang melibatkan ekspektasi positif mengenai motif-motif dari pihak lain yang berhubungan dengan diri seseorang dalam situasi yang berisiko. Kepercayaan cukup penting dalam relational exchange.

\subsection{Pengertian Perilaku Konsumen (Consumer Behaviour)}

Menurut Kotler dan Keller (2009:166) perilaku konsumen adalah studi tentang bagaimana individu, kelompok, dan organisasi memilih, membeli, menggunakan, dan bagaimana barang, jasa, ide, atau pengalaman untuk memuaskan kebutuhan dan keinginan mereka. Menurut Schiffman dan Kanuk (2007:5) studi perilaku konsumen sebagai ilmu pemasaran yang terpisah dimulai ketika para pemasar menyadari bahwa konsumen tidak selalu bertindak atau memberikan reaksi seperti yang dkemukan oleh teori pemasaran. Adapun menurut Sunyoto (2012:251) perilaku konsumen didefinisikan sebagai kegiatan-kegiatan individu yang secara langsung terlibat dalam mendapatkan dan mempergunakan barang-barang atau jasa termasuk didalamnya proses pengambilan keputusan pada persiapan dan penentuan kegiatan-kegiatan tersebut.

\subsection{Keputusan Pembelian}

Proses psikologi dasar memainkan peranan penting dalam memahami bagaimana konsumen benar-benar membuat keputusan pembelian mereka. Menurut Kotler dan Keller (2009:184) periset pemasaran telah mengembangkan "model tingkat" proses keputusan pembelian. Konsumen melalui lima tahap: pengenalan masalah, pencarian informasi, evaluasi alternatif, keputusan pembelian, dan perilaku pasca pembelian. Berikut ini merupakan gambaran proses keputusan pembelian model lima tahap:

Gambar 1 Tahapan penelitian

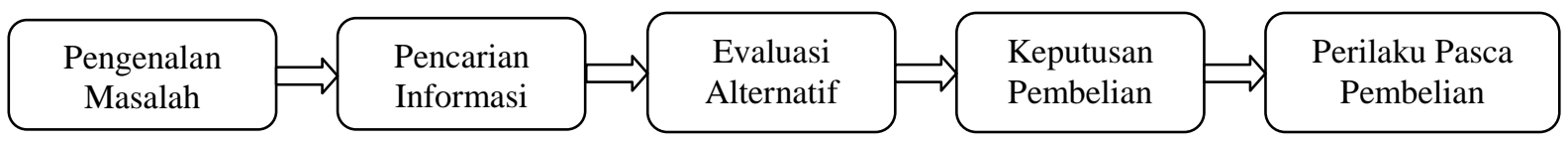

Sumber : Kotler dan Keller (2009:185)

\subsection{Pengertian Loyalitas}

Menurut Ali Hasan (2013:134) loyalitas merupakan kondisi psikologis (attitudinal dan behavioural) yang berkaitan dengan sikap produk, konsumen akan membentuk keyakinan, menetapkan suka dan tidak suka, dan memutuskan apakah mereka ingin membeli produk. Dimensi sikap merupakan niat dan preferensi pelanggan untuk membeli suatu produk atau jasa tertentu. Semakin besar niat pelanggan untuk membeli ulang atau niat untuk merekomendasikan suatu indikasi bahwa perusahaan tersebut mempunyai bisnis yang cerah dimasa depan. Sehingga dimensi sikap ini merupakan indikasi yang baik untuk pengukuran loyalitas pelanggan. Dengan kata lain dimensi ini akan memberikan indikasi apakah pelanggan akan tetap membeli lagi atau pindah pada perusahaan lain. 


\subsection{Pengertian Pelanggan}

Menurut Greenberg (2010:8) pelanggan adalah individu atau kelompok yang terbiasa membeli sebuah produk atau jasa berdasarkan keputusan mereka atas pertimbangan manfaat maupun harga. Kemudian melakukan hubungan dengan perusahaan melalui telepon, surat, dan fasilitas lainnya untuk mendapatkan suatu penawaran baru dari perusahaan. Jadi pelanggan adalah seorang atau sekelompok individu yang terbiasa untuk membeli karena adanya perubahan dean interaksi dalam periode waktu tertentu.

\subsection{Pengertian Loyalitas Pelanggan}

Subroto dan Nasution (2005:21) mengutip definisi loyalitas pelanggan adalah persepsi pelanggan terhadap satu jenis pelayanan yang didapatkannya. Loyalitas pelanggan adalah kunci untuk mendapatkan keuntungan jangka panjang dan tetap memberikan kesenangan kepada pelanggan adalah merupakan kebutuhan bisnis setiap orang.

\section{Metode Penelitian}

\subsection{Operasional Variabel}

\begin{tabular}{|c|c|c|c|c|}
\hline Variabel & $\begin{array}{c}\text { Definisi } \\
\text { Operasional } \\
\end{array}$ & Indikator & Ukuran & Skala \\
\hline $\begin{array}{l}\text { Brand Equity } \\
\text { (X1) }\end{array}$ & $\begin{array}{l}\text { Seperangkat aset } \\
\text { dan liabilitas } \\
\text { merek yang } \\
\text { berkaitan dengan } \\
\text { suatu merek. }\end{array}$ & $\begin{array}{l}\text { Brand Awareness } \\
\text { (Kesadaran Merek) } \\
\text { Perceived Quality } \\
\text { (Persepsi Kualitas) } \\
\text { Brand Association } \\
\text { (Asosiasi Merek) } \\
\\
\text { Brand Loyaty (Loyaltitas } \\
\text { Merek) }\end{array}$ & $\begin{array}{l}\text {-Produk Teh Botol } \\
\text { Sosro yang mudah } \\
\text { diingat } \\
\text {-rasa yang enak } \\
\text {-Higenis atau bersih } \\
\text {-simbol yang menarik } \\
\text {-menolak membeli } \\
\text { merek lain } \\
\\
\text {-menyarankan untuk } \\
\text { membeli kepada orang } \\
\text { lain }\end{array}$ & $\begin{array}{l}\text { Ordinal } \\
\text { Ordinal } \\
\text { Ordinal }\end{array}$ \\
\hline $\begin{array}{l}\text { Brand trust } \\
\text { (X2) }\end{array}$ & $\begin{array}{l}\text { Kepercayaan } \\
\text { Pelanggan } \\
\text { Terhadap merek } \\
\text { Teh Botol Sosro } \\
\text { dan perusahaan }\end{array}$ & $\begin{array}{l}\text { Brand Characteristic } \\
\text { (Karakteristik Merek) } \\
\\
\text { Company Characteristic } \\
\text { (Karakteristik } \\
\text { Perusahaan) } \\
\\
\text { Consumer-Brand } \\
\text { Characteristic } \\
\text { (Karakteristik } \\
\text { Pelanggan-Merek) }\end{array}$ & $\begin{array}{l}\text {-merek telah dipercaya } \\
\text {-mampu memenuhi } \\
\text { kebutuhan pelanggan } \\
\text {-reputasi perusahaan } \\
\text { yang baik } \\
\text {-banyak disukai } \\
\text { masyarakat } \\
\text {-konsumen merasa puas } \\
\text {-pelanggan menyukai } \\
\text { merek teh bool sosro } \\
\text { dan pelanggan yang } \\
\text { lain. }\end{array}$ & Ordinal \\
\hline
\end{tabular}




\begin{tabular}{|c|c|c|c|c|}
\hline Variabel & $\begin{array}{c}\text { Definisi } \\
\text { Operasional } \\
\end{array}$ & Indikator & Ukuran & Skala \\
\hline $\begin{array}{l}\text { Loyalitas } \\
\text { Pelanggan } \\
(\mathrm{Y})\end{array}$ & $\begin{array}{l}\text { Komitmen untuk } \\
\text { melakukan } \\
\text { pembelian ulang } \\
\text { produk }\end{array}$ & $\begin{array}{l}\text { Repeat Purchase } \\
\text { (Pembelian Ulang) } \\
\text { Retention } \\
\text { Referalls }\end{array}$ & $\begin{array}{l}\text {-melakukan pembelian } \\
\text { ke warung atau outlet } \\
\text {-apapun makanannya } \\
\text { selalu meminum teh } \\
\text { botol sosro } \\
\text {-tetap membeli di masa } \\
\text { yang akan datang. } \\
\text {-Informasi positif } \\
\text { kepada orang lain. } \\
\text {-Anjuran kepada orang } \\
\text { lain untuk membeli. }\end{array}$ & Ordinal \\
\hline
\end{tabular}

\subsection{Populasi dan Sampel}

Populasi dalam penelitian ini adalah mahasiswa aktif S1 Manajemen STIE Ekuitas angkatan 2011-2013 yang berjumlah 975 orang karena termasuk kedalam segmen pasar yang dituju.

Menurut Sugiyono (2012:62) sampel adalah bagian dari jumlah dan karakteristik yang dimiliki oleh populasi tersebut.Sampel yang diambil dari populasi harus dapat mewakili keseluruhan populasi yang ada. Teknik pengambilan sampel yang digunakan rumus yang dikemukakan oleh Stovin yang dikutip oleh Husein Umar (2005:141), untuk menghitung penentuan jumlah sampel dari populasi tersebut maka digunakan rumus Slovin sebagai berikut:

Rumus Solvin:

Keterangan :

$$
\mathrm{n}=\frac{N}{N \cdot d^{2+1}}
$$

$\mathrm{N}=$ ukuran sample

$\mathrm{N}=$ Populasi

$\mathrm{d}=$ galat pendugaan atau batas kesalahan

Dalam menentukan jumlah sampel yang dipilih, penulis menggunakan tingkat kesalahan sebesar 10\% karena dalam setiap penelitian tidak mungkin hasilnya sempurna 100\%, semakin kecil tingkat kesalahan maka semakin banyak ukuran sampel. Jumlah populasi yang digunakan adalah 975 orang, jumlah populasi ini didapat dari jumlah mahasiswa STIE Ekuitas S1 Manajemen angkatan tahun 2011-2013 dengan perhitungan diatas maka: 975

$\mathrm{n}=\overline{975 \times 0,1^{2}+1}$

$=90,70$ atau 91 orang

Jadi dari anggota populasi yang diambil sebagai sampel adalah sebanyak 91 orang responden.

Adapun teknik pengambilan sampel yang digunakan adalah teknik sampling kebetulan atau biasa disebut accidental sampling yaitu bentuk sampling nonprobabilitas dimana anggota sampelnya yang dipilih, diambil berdasarkan kemudahan mendapatkan data yang diperlukan, atau dilakukan seadanya, seperti mudah ditemui atau dijangkau atau kebetulan ditemukan (Hasan, 2002:68). 


\section{PEMBAHASAN}

\subsection{Hipotesis Penelitian}

$\mathrm{H}_{0} \quad$ : $\rho y x_{1} x_{2}=0$ "variabel brand equity $\left(\mathrm{X}_{1}\right)$ dan brand trust $\left(\mathrm{X}_{2}\right)$ secara simultan tidak berpengaruh signifikan terhadap variabel loyalitas (Y)", $\mathrm{H}_{1}$

: $\rho y x_{1} x_{2} \neq 0$ "variabel brand equity $\left(\mathrm{X}_{1}\right)$ dan brand trust $\left(\mathrm{X}_{2}\right)$ secara simultan berpengaruh signifikan terhadap variabel loyalitas $(\mathrm{Y})$ ".

\subsection{Uji Normalitas}

Tabel 1. Uji Normalitas

\begin{tabular}{|c|c|c|c|c|}
\hline & & $\begin{array}{l}\text { Brand Equity } \\
\text { (X1) }\end{array}$ & $\begin{array}{l}\text { Brand Trust } \\
\text { (X2) }\end{array}$ & $\begin{array}{l}\text { Loyalitas } \\
\text { Pelanggan (Y) }\end{array}$ \\
\hline $\mathrm{N}$ & & 91 & 91 & 91 \\
\hline \multirow[b]{2}{*}{ Normal Parameters ${ }^{\mathrm{a}, \mathrm{b}}$} & Mean & 18.4235 & 15.9464 & 12.5054 \\
\hline & $\begin{array}{l}\text { Std. } \\
\text { Deviation }\end{array}$ & 3.90743 & 3.18314 & 2.87323 \\
\hline \multirow{3}{*}{ Most Extreme Differences } & Absolute & .129 & .101 & .139 \\
\hline & Positive & .083 & .078 & .094 \\
\hline & Negative & -.129 & -.101 & -.139 \\
\hline Kolmogorov-Smirnov Z & & 1.231 & .966 & 1.329 \\
\hline Asymp. Sig. (2-tailed) & & .096 & .308 & .058 \\
\hline
\end{tabular}

Berdasarkan hasil uji normalitas kolmogorov-smirnov, dapat dilihat bahwa nilai sig. Brand Equity sebesar 0.096, nilai sig. Brand Trust sebesar 0.308 dan nilai sig. Loyalitas Pelanggan sebesar 0.058. Tolak $\mathrm{H}_{0}$ jika sig $<\alpha$. Terima $\mathrm{H}_{0}$ dalam hal lain. Dapat dilihat bahwa semua variabel nilai sig. yang didapatkan lebih besar dari nilai $\alpha(0.05)$. Dengan demikian, dapat disimpulkan bahwa data untuk semua variabel berdistribusi normal.

\subsection{Analisa Jalur (Path Analysis)}

\subsubsection{Pengujian Hipotesis}

\section{Pengujian Hipotesis Penelitian}

Kriteria uji, tolak $\mathrm{H}_{0}$ jika $\mathrm{F}_{\text {hitung }}>\mathrm{F}_{\alpha}(\mathrm{k}, \mathrm{n}-\mathrm{k}-1)$, dengan $\mathrm{F}_{\alpha}(\mathrm{k}, \mathrm{n}-\mathrm{k}-1)$ diperoleh dari tabel distribusi $\mathrm{F}$ dengan $\alpha=5 \%$ dan $\mathrm{db}_{1}=\mathrm{k}=2$, dan $\mathrm{db}_{2}=\mathrm{n}-\mathrm{k}-1=91-2-1=88$, sehinggan dari perhitungan didapatkan :

Tabel 2 Uji Hipotesis

\begin{tabular}{lllllll}
\hline & Model & Sum of Squares & df & Mean Square & F & Sig. \\
\hline \multirow{3}{*}{1} & Regression & 447.418 & 2 & 223.709 & 66.604 & $.000^{\mathrm{b}}$ \\
\cline { 2 - 7 } & Residual & 295.572 & 88 & 3.359 & & \\
\cline { 2 - 6 } & Total & 742.990 & 90 & & & \\
\hline
\end{tabular}

Berdasarkan output pada tabel 2, diperoleh nilai $\mathrm{F}_{\text {hitung }}$ sebesar 66.604 dengan nilai sig. sebesar 0,000. Dengan tingkat signifikansi $10 \%$, maka didapatkan $\mathrm{F}_{\text {tabel }}=3,10$. Karena nilai $\mathrm{F}_{\text {hitung }}>$ $\mathrm{F}_{\text {tabel }}(66.604>3,10)$ dan nilai sig. $\leq \alpha(0,000 \leq 0,05)$, maka $\mathrm{H}_{0}$ ditolak. Artinya, terdapat pengaruh signifikan secara simultan variabel Brand Equity $\left(\mathrm{X}_{1}\right)$ dan Brand Trust $\left(\mathrm{X}_{2}\right)$ terhadap Loyalitas Pelanggan (Y). Dari tabel di atas, diperoleh nilai $F_{\text {hitung }}$ sebesar 66.604. Karena nilai $F_{\text {hitung }}(66.604)$ $>\mathrm{F}_{\text {tabel }}(3,10)$ maka Ho ditolak. Dengan demikian dapat disimpulkan bahwa secara simultan 
terdapat pengaruh yang signifikan antara Brand Equity $\left(\mathrm{X}_{1}\right)$ dan Brand Trust $\left(\mathrm{X}_{2}\right)$ terhadap Loyalitas Pelanggan (Y).

\section{Pengujian sub hipotesis penelitian}

Untuk mengetahui seberapa jauh pengaruh variabel independen secara individual / parsial dalam menjelaskan variasi variabel dependen, maka dilakukan uji t (Ghozali, 2012 : 88). Brand Equity Terhadap Loyalitas Pelanggan $\mathrm{H}_{0}: \rho y x_{1}=0$ Tidak terdapat pengaruh yang signifikan Brand Equity terhadap Loyalitas Pelanggan. $\mathrm{H}_{1}: \rho y x_{1} \neq 0 \quad$ Terdapat pengaruh yang signifikan Brand Equity terhadap Loyalitas Pelanggan, Brand Trust Terhadap Loyalitas Pelanggan $\mathrm{H}_{0}: \rho y x_{2}=0$ Tidak terdapat pengaruh yang signifikan Brand Trust terhadap Loyalitas Pelanggan. $\mathrm{H}_{1}: \rho y x_{2} \neq 0$ Terdapat pengaruh yang signifikan Brand Trust terhadap Loyalitas Pelanggan, Hasil Uji t analisa jalur

Tabel 3 uji statistic

\begin{tabular}{|c|c|c|c|c|c|c|}
\hline \multirow[t]{2}{*}{ Model } & & $\begin{array}{l}\text { Unst: } \\
\text { Coef }\end{array}$ & $\begin{array}{l}\text { dardized } \\
\text { cients }\end{array}$ & $\begin{array}{l}\text { Standardize } \\
\text { d }\end{array}$ & $\mathrm{t}$ & Sig. \\
\hline & (Constant) & $\begin{array}{l}\text { B } \\
.204\end{array}$ & $\begin{array}{l}\text { Std. Error } \\
1.105\end{array}$ & Beta & .185 & .854 \\
\hline \multirow[t]{2}{*}{1} & $\begin{array}{l}\text { Brand } \quad \text { Equity } \\
\text { (X1) }\end{array}$ & .411 & .057 & .559 & 7.228 & .000 \\
\hline & Brand Trust (X2) & .296 & .070 & .328 & 4.242 & .000 \\
\hline
\end{tabular}

Melalui tabel distribusi t student dengan tingkat kepercayaan 90\% pada setiap variabel bebas didapatkan nilai $t_{\text {tabel }}$ sebesar 1,987. Dengan kriteria uji tolak $H_{0}$ jika $t_{\text {hitung }}>t_{\text {tabel }}$ atau nilai signifikansi (sig.) $<0.05$. maka dari tabel dapat dilihat bahwa $\mathrm{t}_{\text {hitung }}$ Brand Equity $\left(\mathrm{X}_{1}\right)>\mathrm{t}_{\text {tabel }}(7.228$ $>1,987)$ dan nilai sig. $\leq \alpha(0,000 \leq 0,05)$ serta $t_{\text {hitung Brand Trust }}\left(\mathrm{X}_{2}\right)>\mathrm{t}_{\text {tabel }}(4.242>1,987)$ dan nilai sig. $\leq \alpha(0,000 \leq 0,05)$, artinya Brand Equity $\left(\mathrm{X}_{1}\right)$ dan Brand Trust $\left(\mathrm{X}_{2}\right)$ memiliki pengaruh yang signifikan terhadap Loyalitas Pelanggan $(\mathrm{Y})$ secara sendiri-sendiri (parsial).

\subsubsection{Analisa Jalur Model Pengaruh Brand Equity (X1) dan Brand Trust (X2) terhadap Loyalitas Pelanggan (Y)}

1. Koefisien korelasi

\begin{tabular}{cccc} 
Korelasi & \multicolumn{4}{c}{ Antar Variabel (Correlation Matrix) } \\
& X1 & X2 & Y \\
X1 & ------- & ------- & ------- \\
X2 & 0.495 & 1.000 & \\
Y & 0.722 & 0.605 & 1.000
\end{tabular}

Tabel diatas menunjukkan bahwa : Kuat hubungan antara Brand Equity $\left(\mathrm{X}_{1}\right)$ dan Loyalitas Pelanggan (Y) adalah sebesar 0,722. Hal ini menunjukan bahwa hubungan antara Brand Equity dan Loyalitas Pelanggan mencapai taraf hubungan antara dua variabel tersebut kuat. Kuat hubungan antara Brand Trust $\left(\mathrm{X}_{2}\right)$ dan Loyalitas Pelanggan $(\mathrm{Y})$ adalah sebesar 0,605. Hal ini menunjukan bahwa hubungan antara Brand Trust dan Loyalitas Pelanggan mencapai taraf hubungan antara dua variabel tersebut kuat. Kuat hubungan antara Brand Equity $\left(\mathrm{X}_{1}\right)$ dan Brand Trust $\left(\mathrm{X}_{2}\right)$ adalah sebesar 0,495. Hal ini menunjukan bahwa hubungan antara Brand Equity dan Brand Trust mencapai taraf hubungan antara dua variabel tersebut cukup kuat. 


\section{Koefisien Determinasi}

Perhitungan besarnya koefisien determinasi antar variabel independen terhadap variabel dependen dilakukan sebagai berikut ini: Koefisien Determinasi Persamaan Struktural

Tabel 4 Koefisien Determinasi

\begin{tabular}{lllllc}
\hline Model & $\mathrm{R}$ & R Square & Adjusted R Square & $\begin{array}{l}\text { Std. Error of } \\
\text { Estimate }\end{array}$ & theDurbin-Watson \\
\hline 1 & $.776^{\mathrm{a}}$ & .602 & .593 & 1.83269 & 2.036 \\
\hline
\end{tabular}

$\mathbf{P}_{\mathrm{Y} \varepsilon}=1-r_{Y X 1 X 2}^{2}, \mathbf{P}_{\mathrm{Y} \varepsilon}=1-0,602=0,398$

Dari hasil perhitungan tersebut diperoleh nilai $\mathbf{P}_{\mathrm{Y} \varepsilon}$ sebesar 0,398. Ini berarti bahwa besarnya pengaruh dari variabel lain terhadap variabel Loyalitas Pelanggan (Y) di luar kedua variabel Brand Equity $\left(\mathrm{X}_{1}\right)$ dan Brand Trust $\left(\mathrm{X}_{2}\right)$ tersebut adalah $39,8 \%$. nilai koefisien korelasi $(\mathrm{R})$ sebesar 0,776 yang berarti bahwa korelasi atau hubungan antara variabel Loyalitas Pelanggan dengan variabel Brand Equity dan Brand Trust tergolong kuat. Angka $R$ square atau koefisien determinasi adalah 0,602 . Hal ini berarti $60.2 \%$ variasi atau perubahan pada variabel Loyalitas Pelanggan dapat dijelaskan oleh variabel Brand Equity dan Brand Trust sedangkan sisanya sebesar 39,8\% dijelaskan oleh faktor-faktor lain di luar model yang diteliti

3. Koefisien jalur

Hasil Koefisien Jalur (Path Analisis)

Tabel 5 Koefisien Jalur

\begin{tabular}{lllllll}
\hline \multirow{2}{*}{ Model } & & \multicolumn{2}{l}{ Unstandardized Coefficients } & $\begin{array}{l}\text { Standardized } \\
\text { Coefficients }\end{array}$ & $\mathrm{t}$ & \multirow{2}{*}{ Sig. } \\
\cline { 3 - 6 } & & $\mathrm{B}$ & Std. Error & Beta & \\
\hline \multirow{2}{*}{1} & .204 & 1.105 & & .185 & .854 \\
\cline { 2 - 7 } & (Constant) & .411 & .057 & .559 & 7.228 & .000 \\
\cline { 2 - 7 } & Brand Equity (X1) & .296 & .070 & .328 & 4.242 & .000 \\
\hline
\end{tabular}

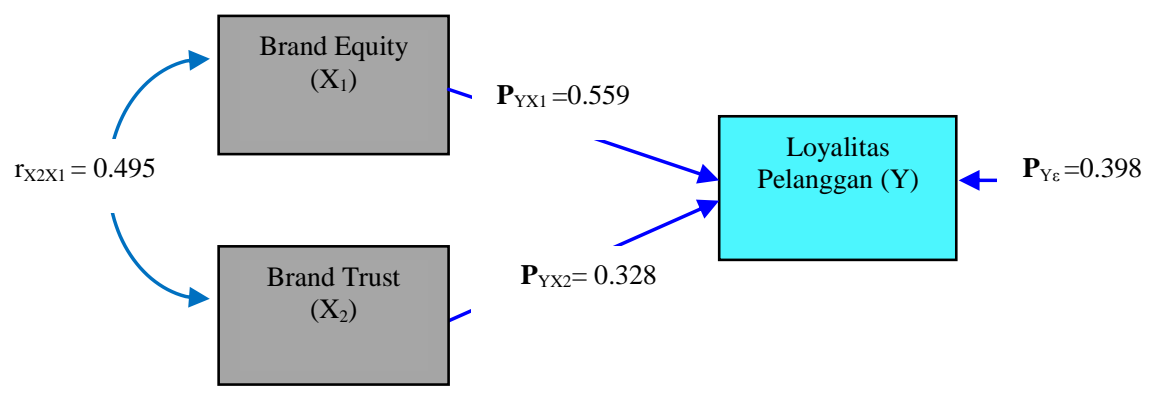

Gambar 2 analisa Jalur

Diagram Jalur Pengaruh Brand Equity $\left(\mathrm{X}_{1}\right)$ dan Brand Trust $\left(\mathrm{X}_{2}\right)$ Terhadap Loyalitas Pelanggan (Y) 
Berdasarkan Gambar diatas kerangka hubungan kausal empiris antara Brand Equity $\left(\mathrm{X}_{1}\right)$ dan Brand Trust $\left(\mathrm{X}_{2}\right)$ terhadap Loyalitas Pelanggan (Y) dibuat model struktur sebagai berikut:

$\begin{aligned} \mathrm{Y} & =\mathbf{P}_{\mathrm{YX} 1} \mathrm{X}_{1}+\mathbf{P}_{\mathrm{YX} 2} \mathrm{X}_{2}+\mathbf{P}_{\mathrm{Y} \varepsilon} \\ & =0,559 \mathrm{X}_{1}+0,328 \mathrm{X}_{2}+0,398 \varepsilon\end{aligned}$

Hasil analisis jalur dari Gambar 4.4 menunjukkan koefien jalur variabel Brand Equity $\left(\mathrm{X}_{1}\right)$ secara langsung terhadap Loyalitas Pelanggan (Y) adalah sebesar 0,559 yang berarti mempunyai nilai positif, hal ini menunjukan hubungan searah antara Brand Equity $\left(\mathrm{X}_{1}\right)$ terhadap Loyalitas Pelanggan (Y), artinya jika setiap terjadi penambahan Brand Equity $\left(\mathrm{X}_{1}\right)$ sebesar satu satuan maka akan menambah Loyalitas Pelanggan (Y) sebesar 0,559. Sedangkan jika setiap terjadi pengurangan Brand Equity $\left(\mathrm{X}_{1}\right)$ sebesar satu satuan maka akan mengurangi Loyalitas Pelanggan (Y) sebesar 0,559. Koefien jalur variabel Brand Trust $\left(\mathrm{X}_{2}\right)$ secara langsung terhadap Loyalitas Pelanggan (Y) adalah sebesar 0,328 yang berarti mempunyai nilai positif, hal ini menunjukan hubungan searah antara Brand Trust $\left(\mathrm{X}_{2}\right)$ terhadap Loyalitas Pelanggan (Y), artinya jika setiap terjadi penambahan Brand Trust $\left(\mathrm{X}_{2}\right)$ sebesar satu satuan maka akan menambah Loyalitas Pelanggan (Y) sebesar 0,328. Sedangkan jika setiap terjadi pengurangan Brand Trust $\left(\mathrm{X}_{2}\right)$ sebesar satu satuan maka akan mengurangi Loyalitas Pelanggan (Y) sebesar 0,328, Sedangkan untuk mengetahui besarnya pengaruh langsung dan tidak langsung variabel Brand Equity $\left(\mathrm{X}_{1}\right)$ dan Brand Trust $\left(\mathrm{X}_{2}\right)$ terhadap variabel Loyalitas Pelanggan (Y) dapat ditentukan melalui perhitungan : Pengaruh Langsung Dan Tidak Langsung Variabel Independen Terhadap Variabel Dependen Pada Model Persamaan Struktural

Tabel 6. Pengaruh langsung dan tidak langsung

\begin{tabular}{|c|c|c|c|c|}
\hline \multirow{2}{*}{ Jalur } & \multirow{2}{*}{ Pengaruh Langsung (\%) } & $\begin{array}{l}\text { Pengaruh } \\
\text { Langsung }(c\end{array}$ & Tidak & \multirow{2}{*}{$\begin{array}{l}\text { Pengaruh } \\
\text { Total }\end{array}$} \\
\hline & & Melalui $\mathrm{X}_{1}$ & $\begin{array}{l}\text { Melalui } \\
\mathrm{X}_{2}\end{array}$ & \\
\hline $\mathrm{X}_{1}$ & 31,25 & - & 9,08 & 40,33 \\
\hline$X_{2}$ & 10,76 & 9,08 & - & 19.84 \\
\hline \multicolumn{4}{|c|}{ Pengaruh Langsung \& Tak Langsung X1 dan X2 Terhadap Y } & 60.2 \\
\hline \multicolumn{4}{|c|}{$\begin{array}{l}\text { Pengaruh Langsung \& Tak Langsung Diluar X1 dan X2 Terhadap } \\
\text { Y }\end{array}$} & 39.8 \\
\hline
\end{tabular}

Berdasarkan tabel diatas dapat kita interpretasikan beberapa hal sebagai berikut : Pengaruh Langsung : 1 . Koefisien jalur $\rho_{\mathrm{yx} 1}$ sebesar 0.559 artinya variabel Brand Equity memiliki pengaruh secara langsung terhadap Loyalitas Pelanggan sebesar $\rho_{\mathrm{yx} 1}^{2} \times 100 \%=(0.559)^{2} \times 100 \%$ atau sebesar 31,25\%. 2. Koefisien jalur $\rho_{\mathrm{yx} 2}$ sebesar 0.328 artinya variabel Brand Trust memiliki pengaruh secara langsung terhadap Loyalitas Pelanggan sebesar $\rho_{\mathrm{yx} 2}^{2} \times 100 \%=(0.328)^{2} \times 100 \%$ atau sebesar 10,76\%. Pengaruh Tidak Langsung 1.Pengaruh variabel Brand Equity melalui variabel Brand Trust secara tidak langsung terhadap Loyalitas Pelanggan adalah sebesar $\left(\rho_{\mathrm{yx} 1}^{2} \mathrm{x}\right.$ $\left.\mathrm{r}_{\mathrm{x} 1 \times 2} \times \rho_{\mathrm{yx} 2}^{2}\right) \times 100 \%=(0.559 \times 0.495 \times 0.328) \times 100 \%$ atau sebesar $9,08 \% .2$. Pengaruh variabel Brand Trust melalui variabel Brand Equity secara tidak langsung terhadap Loyalitas Pelanggan adalah sebesar $\left(\rho_{\mathrm{yx} 2}^{2} \times \mathrm{r}_{\mathrm{x} 1 \times 2} \times \rho_{\mathrm{yx} 1}^{2}\right) \times 100 \%=(0.328 \times 0.495 \times 0.559) \times 100 \%$ atau sebesar $9,08 \%$. Pengaruh Total 1. Pengaruh total variabel Brand Equity terhadap Loyalitas Pelanggan adalah sebesar 31,25\% $+9,08 \%=40,33 \%$. 2.Pengaruh total variabel Brand Trust terhadap Loyalitas Pelanggan adalah sebesar 10,76\% $+9,08 \%=19.84 \%$. 3.Pengaruh total variabel Brand Equity dan Brand Trust terhadap Loyalitas Pelanggan adalah sebesar 40,33\% $+19.84 \%=60.2 \%$. Pengaruh total terhadap Loyalitas Pelanggan di luar pengaruh Brand Equity dan Brand Trust adalah sebesar $100 \%-60.2 \%=39.8 \%$. 


\section{Kesimpulan dan Saran}

\subsection{KESIMPULAN}

1. Dari hasil kriteria uji $\mathrm{H}_{0}$ jika $\mathrm{t}_{\text {hitung }}>\mathrm{t}_{\text {tabel }}$ atau nilai signifikansi (sig.) $<0.05$. maka dari tabel dapat dilihat bahwa $\mathrm{t}_{\text {hitung }}$ Brand Equity $\left(\mathrm{X}_{1}\right)>\mathrm{t}_{\text {tabel }}(7.228>1,987)$ dan nilai sig. $\leq \alpha$ $(0,000 \leq 0,05)$ serta $t_{\text {hitung }}$ Brand Trust $\left(X_{2}\right)>t_{\text {tabel }}(4.242>1,987)$ dan nilai sig. $\leq \alpha(0,000$ $\leq 0,05)$, artinya Brand Equity $\left(\mathrm{X}_{1}\right)$ yang diindikatorkan oleh brand awareness, perceived quality, brand association, brand loyalty dan Brand Trust $\left(\mathrm{X}_{2}\right)$ yang diindikatorkan oleh brand characteristic, company characteristic dan consumer brand characteristic memiliki pengaruh yang signifikan terhadap Loyalitas Pelanggan (Y),konsumen tidak terpengaruh pada citra negatif mengenai perusahaan, dan referensi total mengenai eksistensi perusahaan secara sendiri-sendiri (parsial). Kuat hubungan antara Brand Equity $\left(\mathrm{X}_{1}\right)$ dan Loyalitas Pelanggan (Y) adalah sebesar 0,722. Hal ini menunjukan bahwa hubungan antara Brand Equity dan Loyalitas Pelanggan mencapai taraf hubungan antara dua variabel tersebut kuat.

2. Hasil analisis jalur variabel Brand Equity $\left(\mathrm{X}_{1}\right)$ yang diindikatorkan oleh brand awareness, perceived quality, brand association, brand loyalty secara langsung terhadap Loyalitas Pelanggan (Y), konsumen tidak terpengaruh pada citra negatif mengenai perusahaan, dan referensi total mengenai eksistensi perusahaan adalah sebesar 0,559 yang berarti mempunyai nilai positif, hal ini menunjukan hubungan searah antara Brand Equity $\left(\mathrm{X}_{1}\right)$ terhadap Loyalitas Pelanggan (Y), artinya jika setiap terjadi penambahan Brand Equity $\left(\mathrm{X}_{1}\right)$ sebesar satu satuan maka akan menambah Loyalitas Pelanggan $(\mathrm{Y})$ sebesar 0,559. Sedangkan jika setiap terjadi pengurangan Brand Equity $\left(\mathrm{X}_{1}\right)$ sebesar satu satuan maka akan mengurangi Loyalitas Pelanggan (Y) sebesar 0,559.

3. Hasil analisis jalur variabel Brand Trust $\left(\mathrm{X}_{2}\right)$ yang diindikatorkan oleh brand characteristic, company characteristic dan consumer brand characteristic secara langsung terhadap Loyalitas Pelanggan (Y) yang diindikatorkan oleh pembeli secara berulang-ulang yang dilakukan oleh konsumen, konsumen tidak terpengaruh pada citra negatif mengenai perusahaan, dan referensi total mengenai eksistensi perusahaan adalah sebesar 0,328 yang berarti mempunyai nilai positif, hal ini menunjukan hubungan searah antara Brand Trust $\left(\mathrm{X}_{2}\right)$ terhadap Loyalitas Pelanggan $(\mathrm{Y})$, artinya jika setiap terjadi penambahan Brand Trust $\left(\mathrm{X}_{2}\right)$ sebesar satu satuan maka akan menambah Loyalitas Pelanggan $(\mathrm{Y})$ sebesar 0,328. Sedangkan jika setiap terjadi pengurangan Brand Trust $\left(\mathrm{X}_{2}\right)$ sebesar satu satuan maka akan

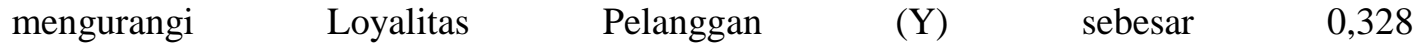

\subsection{Saran}

1. Dari hasil penelitian ini terlihat bahawa terdapat hubungan yang kuat antara brand equty dan loyalitas, sehingga hal ini daapt menjadi tantangan bagi produsen bagaiamn caranya agara hubungan tersebut tetap abadi dengan menciptakan produk yang terjamin mutunya sehingga ekpektasi pelanggan selalu terpenuhi

2. Terlihat juga bahwa pelanggan tidka terpengaruh denan berita negative, oleh karena itu produsen harus memprtahankan terus loyalitas pelanggan dengna strategi pemasaran yang mumpuni sehingga dapt menjadi market leader

3. Produsen harus mempertahankan ciri khas produk terutama kualitas, rasa, varian produk, kemasan serta citarasa dan karakter perusahaan yang sudah membumi dengan pelanggan

\section{DAFTAR PUSTAKA}

Aaker, (2006) Manajemen Ekuitas Merek, Jakarta : Spektrum Mitra Utama 
Adrian Payne (2007), The Essence of Service Marketing (Pemasaran Jasa) .Jakarta: Salemba Empat

Agus W. Soehadi (2005), Effective Branding Konsep Dan Aplikasi Pengembangan Merek, Quantum Bisnis Dan Manajemen. Bandung

Al-Rasyid, (2005), Dasar-Dasar Statistika Terapan, Program Pascasarjana, Unpad : Bandung.

Amin, Widjaja, Tunggal (2008), Dasar-dasar Customer Relationship Management, Jakarta: Harvarindo.

BAAK STIE Ekuitas 2013

Christiaan Rudolf Quintus Roets, Ayesha Lian Bevan-Dye, Willem Peet Viljeon, Ananto Sukendar Influence of Social Image and Brand Trust on Mobile Phone Brand Equity amongst African Generation Y Students

Dokumen Perusahaan PT Sinar Sosro

Doney, P., \& Cannon, J.P. (2006). An examination of the nature of trust in buyer-seller relationships. Journal of Marketing, 61, 35-51.

Ferrinadewi, Erna. (2008) Jurnal Pengarauh Threat Emotion Konsumen dan Brand Trust Pada Keputusan Pembelian Produk Susu Anlene di Surabaya, Universitas Widya Kartika.

Greenberg, Paul. (2010). Customer Relationship Management at the Speed of Light. Berkeley: Mc-Graw Hill

Griffin, Jill (2007) Customer Loyalty: How To Learn It, How To Keep It. Jakarta: Penerbit Erlangga

Hasan, Ali (2008), Marketting, Yogyakarta, Media Pressindo , (2013) Marketing, Yogyakarta, Media Pressindo

Indriantoro, Nur.dan Bambang Supomo. (2009). Metodologi Penelitian Bisnis:

Untuk Akuntansi dan Manajemen. Edisi I. Yogyakarta: BPFE.

Husein Umar (2005), Metode Riset Bisnis. Jakarta : PT Gramedia Pustaka Utama

Kartajaya, Hermawan. (2009). Marketing Plus : Siasat Memenangkan Persaingan Global. Erlangga. Jakarta

Lau dan Lee (2005) Consumers Trust in a Brand and the Link to Brand Loyalty, Journal of Market Focused Management

Leon Schiffman dan Lesie Lazar Kanuk (2007) Perilaku Konsumen (edisi ketuju), PT Indeks, Jakarta

Morgan, R. M., \& Hunt, S. D. (2005). The commitment-trust theory of relationship marketing. Journal of Marketing, 58(3), 20-38. 
Muchsin, Saggaff, Shihab (2008) Pengaruh Brand Trust dan Brand Equity Terhadap Loyalitas Konsumen Produk Tes Widal Merek Remel

Nuruni Ika dan Kustini. (2011). Experientiall marketing, Emotional Branding, And Brand Trust And Their Effect On Loyalty On Honda Motor Cycle Product. 196 Journal of Economics, Business and Accountancy Ventura. Vol. 14 No. 1.

pp 19-28

Philip Kotler and Kevin Lane Keller (2005) Manajemen Pemasaran, Edisi Kesebelas, Jilid 1, Jakarta: PT Indeks Kelompok Gramedia

Klaten.

(2006), Manajemen Pemasaran. Jakarta : PT. Intan Sejati (2007). Manajemen Pemasaran edisi 12 jilid 1, Jakarta, PT

Macanan Jaya Cemerlang.

, (2008) Manajemen Pemasaran, Jakarta, PT Macanan

Jaya Cemerlang

, (2009) Manajemen Pemasaran, Edisi 12 Jilid 1,

PT. Indeks, Jakarta.

, (2010), Manajemen Pemasaran, Jilid 1, Edisi Ketiga

belas, Penerbit Erlangga, Jakarta

Riduwan dan Kuncoro, (2010) Cara Menggunakan dan Memaknai Path Analysis. Bandung : Alfabeta.

ketujuh).Bandung :Alfabeta

Saladin, Djaslim, (2006), Manajemen Pemasaran, Edisi Keempat, Bandung : Linda Karya

Schiffman, Leon G, and Kanuk, Leslie Lazar, (2006). Perilaku Konsumen, Jakarta : PT Indeks.

Simamora., (2005) Manajemen Pemasaran Internasional. Jakarta : PT Rineka Cipta

Speakman (2005), Lower Urinary Tract Symptom Suggestive of Benign Prostate Hyperplasia (LUTS/BPH) : More Than Treating Symptoms. European Urology Supplements 7th Edition. 680-589.

Subroto, Budiarto dan Nasution, Dolly Suntajaya (2005), Pengukuran Tingkat Kepuasan Pelanggan. Manajemen Usahawan Lembaga Manajemen FE UI. Jakarta.

Sugiyono (2005), Statistik Untuk Penelitian, Cetakan Kelima, Bandung : CV. Alfabeta. 
, (2008), Metode Penelitian Bisnis, Bandung. Alfabeta

, (2012). Metode Penelitian Kuantitatif Kualitatif dan R\&D. Bandung: Alfabeta.

, (2012), Dasar-Dasar Manajemen Pemasaran. Penerbit CAPS. Yogyakarta.

Tjiptono, Fandy dan Anastasia Diana. (2005), Brand Management \& Strategy.Yogyakarta: Penerbit Andi 